Article

\title{
Innovative Carpentry and Hybrid Joints in Contemporary Wooden Architecture
}

\author{
Joanna Ludmiła Arlet
}

check for

updates

Citation: Arlet, Joanna Ludmiła. 2021. Innovative Carpentry and Hybrid Joints in Contemporary Wooden Architecture. Arts 10: 64. https://doi.org/10.3390/arts10030064

Academic Editor: Thor J. Mednick

Received: 14 June 2021

Accepted: 2 September 2021

Published: 7 September 2021

Publisher's Note: MDPI stays neutral with regard to jurisdictional claims in published maps and institutional affiliations.

Copyright: (C) 2021 by the author. Licensee MDPI, Basel, Switzerland. This article is an open access article distributed under the terms and conditions of the Creative Commons Attribution (CC BY) license (https:/ / creativecommons.org/licenses/by/ $4.0 /)$.
Faculty of Architecture, West Pomeranian University of Technology, Żołnierska 50, 71-210 Szczecin, Poland; jarlet@zut.edu.pl

\begin{abstract}
Timber frame structures have a long and rich tradition. In addition to their functional and structural value, they are important elements of the cultural landscape. At the turn of the 21st century, concern for nature, resulting from the threat of environmental degradation, contributed to a growing interest in wooden constructions. For these reasons, we have observed the erection of buildings with wooden frame structures in many countries around the world. This trend contributed to the rapid development of wooden structures, new technologies, and innovative architectural solutions. The conducted research mainly focused on the joints used in their construction, as well as their perception. From among many examples, some original and innovative solutions were selected and analyzed. Their creators are famous architects: Renzo Piano, Imre Makovecz, Jürgen Meyer, Kengo Kuma, and Shigeru Ban. The objects presented in this article are distinguished by the originality of their form and by the fact that they are clearly inspired by vernacular architecture. Crucial elements of these objects, such as wooden, steel, and hybrid connections, are analyzed in this article. Because they are intentionally exposed, they play an important aesthetic role in addition to a structural one.
\end{abstract}

Keywords: wooden architecture; carpentry joints; tradition; innovation; artistic role

\section{Introduction}

The application of environmentally friendly construction materials and modern technologies allows relatively cheap and robust structures to be erected quickly. Due to their usability, light structure, low construction costs and, with proper maintenance, high durability, interest in timber frame structures for buildings is growing.

This trend has been developed and established by renowned architects and constructors who create impressive architectural objects. The avant-garde application of timber and the use of structures and joints that are innovative, yet based on traditional techniques, are characteristic of the works of such architects as: Renzo Piano, Imre Makovecz, Jürgen Meyer, Kengo Kuma, and Shigeru Ban. In this article, we take a closer look at the innovative qualities of the wooden structures used in their works, including carpentry joints. In addition to their structural and usability functions, these joints add a completely new quality. We also analyze traditional carpentry joints, which are the archetypes of modern solutions.

\section{Scope and Methodology of Research}

The fall of carpentry traditions in Europe in the second half of the 20th century, as observed in the course of the research, raised questions about the possibility and purposefulness of their continuation.

However, at the turn of the 20th and 21st centuries, we witnessed dynamic changes in the methods of wood processing and protection. Therefore, the following factors were analyzed: technologies that contributed to the extension of the scope of their application, changes in carpentry techniques, and the innovative combinations applied.

Historical research was carried out to pinpoint traditional timber structures and the timber joints used, which can be a source of inspiration. Then, ex post studies were carried 
out on newly designed and completed buildings by the end of the 2020s, or even some buildings currently under construction. Due to their huge number, the research was limited to objects designed by architects recognized and awarded for their innovation in the design of wooden objects.

Then, from the works of these authors, objects were selected in which wooden frame structures play a fundamental and innovative role. Logical analyses were carried out, including an analysis of the structure, in terms of the solutions implemented, as well as an analysis of wooden and hybrid joints in terms of their innovation and prototypes. The key subject of the research was the new possibilities of the wooden joints presented, the quality of their workmanship and their artistic value.

In the Discussion chapter, the questions posed in the article are revisited and arguments are presented to support the theses contained therein. The structures and original or modified historical joints discussed in Section 5 are summarized in Table 1. This stage led to the conclusions of the conducted research, which are presented in the Conclusions chapter.

Table 1. Contains and organizes the discussed in chapter 5: constructions, original or modified historical joints, and their inspirations.

\begin{tabular}{|c|c|c|c|}
\hline Architect & Object & $\begin{array}{c}\text { Structures and Joints Described in the } \\
\text { Article }\end{array}$ & Inspirations \\
\hline \multirow[t]{6}{*}{ Imre Makovecz } & $\begin{array}{c}\text { Funeral Chapel (1975) at the } \\
\text { Farkasrét Cemetery in } \\
\text { Budapest }\end{array}$ & $\begin{array}{l}\text { The structure of the chapel's interior is } \\
\text { shaped by distinctly curved wooden ribs }\end{array}$ & $\begin{array}{l}\text { Anthropomorphic wooden } \\
\text { forms, resembling bent ribs, } \\
\text { pinned together by a spine }\end{array}$ \\
\hline & $\begin{array}{l}\text { Lutheran Church in Siófok } \\
\text { (1987) }\end{array}$ & $\begin{array}{l}\text { The rhythm of wooden rafters and } \\
\text { support beams creates a symbolic } \\
\text { ark-shaped structure }\end{array}$ & $\begin{array}{l}\text { Anthropomorphic wooden } \\
\text { forms-an entrance with a } \\
\text { door decorated with wooden } \\
\text { "wings" and windows in the } \\
\text { shape of eyes }\end{array}$ \\
\hline & $\begin{array}{l}\text { Holy Spirit Church in Paks } \\
\text { (1987) }\end{array}$ & $\begin{array}{l}\text { The form of the building looks like an } \\
\text { upside down boat; the vertical element is } \\
\text { a belfry with an entrance and three high } \\
\text { gables }\end{array}$ & $\begin{array}{l}\text { Tradition of medieval } \\
\text { king-post roof trusses, } \\
\text { the back of the church } \\
\text { resembles a human face }\end{array}$ \\
\hline & $\begin{array}{l}\text { Sepsiszentgyörgy, funeral } \\
\text { chapel (1997) in Romania }\end{array}$ & $\begin{array}{c}\text { Two domes above two naves of the } \\
\text { chapel are contrasted with a tall, sharp } \\
\text { tower, decorated with two pairs of } \\
\text { wooden wings }\end{array}$ & $\begin{array}{l}\text { Picturesque set of forms } \\
\text { covered with wooden shingle }\end{array}$ \\
\hline & $\begin{array}{l}\text { New Reformed Church in } \\
\text { Cluj-Napoca (2008) }\end{array}$ & $\begin{array}{c}\text { The external form of the church, due to } \\
\text { the towers flanking it, resembles a } \\
\text { medieval fortified castle }\end{array}$ & $\begin{array}{l}\text { The inner form is a dynamic } \\
\text { series of wooden ribs } \\
\text { connected by a keystone }\end{array}$ \\
\hline & $\begin{array}{l}\text { Hungarian Pavilion at the } \\
\text { Seville Expo } 1992\end{array}$ & $\begin{array}{l}\text { The pavilion looks like an upturned } \\
\text { wooden hull; elements of the entrance are } \\
\text { made of carved wood }\end{array}$ & $\begin{array}{l}\text { Wooden structure resemble } \\
\text { ribbing with keel, the stem } \\
\text { and sternpost, longitudinal } \\
\text { elements_-girders; and } \\
\text { transverse elements_rabbets }\end{array}$ \\
\hline \multirow[t]{2}{*}{ Renzo Piano } & $\begin{array}{c}\text { Jean-Marie Tjbaou Cultural } \\
\text { Centre in New Caledonia } \\
\text { (1998) }\end{array}$ & $\begin{array}{l}\text { Horizontal wooden planks and curved } \\
\text { ribs from cross-laminated timber were } \\
\text { combined with the wooden structure of } \\
\text { the internal façade with the use of steel } \\
\text { joints and ties }\end{array}$ & Traditional Caledonian huts \\
\hline & $\begin{array}{l}\text { Auditorium in L'Aquila } \\
\text { (2009) }\end{array}$ & $\begin{array}{l}\text { The object consists of three different cubic } \\
\text { forms. The wholly prefabricated wooden } \\
\text { structure consists of a 3D truss and two } \\
\text { laminated sheath layers }\end{array}$ & $\begin{array}{l}\text { The dynamic form of the } \\
\text { facility was to resemble the } \\
2009 \text { earthquake in L'Aquila }\end{array}$ \\
\hline
\end{tabular}


Table 1. Cont.

\begin{tabular}{|c|c|c|c|}
\hline Architect & Object & $\begin{array}{l}\text { Structures and Joints Described in the } \\
\text { Article }\end{array}$ & Inspirations \\
\hline \multirow[t]{8}{*}{ Kengo Kuma } & $\begin{array}{l}\text { Bato Hiroshige Museum of } \\
\text { Art (2000) }\end{array}$ & $\begin{array}{c}\text { The structure of the object is made from } \\
\text { steel combined with cedar wood and } \\
\text { covered with wooden blinds and glass } \\
\text { panes }\end{array}$ & $\begin{array}{l}\text { Woodcuts (ukiyo-e) by the } \\
\text { famous Japanese artist } \\
\text { Hiroshige Ando }\end{array}$ \\
\hline & $\begin{array}{l}\text { GC Prostho Museum } \\
\text { Research Center (2010) in } \\
\text { Kasugai }\end{array}$ & $\begin{array}{l}\text { The wooden lattice structure used in the } \\
\text { building plays a structural role and is } \\
\text { also used for the museum exhibition }\end{array}$ & $\begin{array}{l}\text { The connectors used in } \\
\text { traditional Japanese wooden } \\
\text { toys Chidori. }\end{array}$ \\
\hline & $\begin{array}{c}\text { Starbucks Coffee (2011) in } \\
\text { Tokyo }\end{array}$ & $\begin{array}{l}\text { Modified traditional Japanese Chidori } \\
\text { wood joints are used }\end{array}$ & $\begin{array}{l}\text { As above, but the connections } \\
\text { are diagonal }\end{array}$ \\
\hline & $\begin{array}{l}\text { Yusuhara Wooden Bridge } \\
\text { Museum (2011) }\end{array}$ & $\begin{array}{l}\text { The "wooden bridge" connects two } \\
\text { public utility buildings located on two } \\
\text { sides of a road; the structure consists of a } \\
\text { set of supports built from small elements } \\
\text { of interlaced beams connected by } \\
\text { wooden joints }\end{array}$ & $\begin{array}{c}\text { Traditional Chinese system of } \\
\text { interlocking wooden brackets } \\
\text { called dougong }\end{array}$ \\
\hline & $\begin{array}{l}\text { Sunny Hills pastry shop } \\
\text { (2013) in Tokyo }\end{array}$ & $\begin{array}{l}\text { The form of the building was inspired by } \\
\text { bamboo baskets; joints that connect } \\
\text { wooden elements at an angle were used } \\
\text { on a mass scale }\end{array}$ & $\begin{array}{c}\text { These joints were inspired by } \\
\text { the Jiigoku-Gumi joints as well } \\
\text { as the Shiguchi joints used in } \\
\text { Japanese construction }\end{array}$ \\
\hline & $\begin{array}{l}\text { Toyama Glass Art Museum } \\
\text { (2015) }\end{array}$ & $\begin{array}{l}\text { The cedar boards, glass and mirrors } \\
\text { vertically surround the glass cylinders to } \\
\text { create the softly lighted interior }\end{array}$ & $\begin{array}{l}\text { The interior is supposed to } \\
\text { resemble an illuminated forest }\end{array}$ \\
\hline & $\begin{array}{l}\text { Cafe, Coeda (2017) in } \\
\text { Shizuoka }\end{array}$ & $\begin{array}{l}\text { The structure of the building is } \\
\text { supported by a central tree-shaped pillar; } \\
\text { a hybrid construction was used, as the } \\
\text { wooden frame was reinforced with } \\
\text { carbon fiber rods }\end{array}$ & Japanese wooden pagoda \\
\hline & $\begin{array}{l}\text { Odunpazari Modern Art } \\
\text { Museum (2019) in } \\
\text { Eskisehir }\end{array}$ & $\begin{array}{l}\text { The wooden structure, which resembles a } \\
\text { timber log structure, was named by the } \\
\text { architect as interlocking timber boxes }\end{array}$ & $\begin{array}{l}\text { Both the architecture of the } \\
\text { building, referring to the } \\
\text { surroundings, and the interior } \\
\text { are inspired by the forms of } \\
\text { "wooden boxes" }\end{array}$ \\
\hline \multirow[t]{3}{*}{ Shigeru Ban } & $\begin{array}{l}\text { Takatori Catholic Church in } \\
\text { Nagata-ku (1995) }\end{array}$ & $\begin{array}{l}\text { An unconventional application of } \\
\text { impregnated paper tubes connected with } \\
\text { wooden joints was used in the } \\
\text { construction }\end{array}$ & $\begin{array}{c}\text { A new, cheap and lightweight } \\
\text { material for low objects in } \\
\text { seismic areas }\end{array}$ \\
\hline & $\begin{array}{l}\text { Nine Bridges Country Club } \\
\text { (2006-2009) }\end{array}$ & $\begin{array}{l}\text { This object consists of } 21 \text { bundles of } \\
\text { wooden columns that are curved and } \\
\text { bent towards the top and create an open, } \\
\text { organic structure }\end{array}$ & $\begin{array}{l}\text { The main building was } \\
\text { inspired by traditional Korean } \\
\text { architecture. The construction } \\
\text { of the atrium resembles the } \\
\text { baroque structure of the } \\
\text { church of St. Lawrence in } \\
\text { Turin by Guarino Guarini }\end{array}$ \\
\hline & $\begin{array}{l}\text { Centre Pompidou-Metz } \\
\text { (2010) }\end{array}$ & $\begin{array}{c}\text { Elements of the wooden roof structure } \\
\text { are based on a hexagon, as is the plan of } \\
\text { the entire roof }\end{array}$ & $\begin{array}{l}\text { The roof was inspired by a } \\
\text { Chinese hat. However, the } \\
\text { wooden ribs resemble the } \\
\text { baroque structure of the } \\
\text { church of St. Lawrence in } \\
\text { Turin by Guarino Guarini }\end{array}$ \\
\hline
\end{tabular}


Table 1. Cont.

\begin{tabular}{|c|c|c|c|}
\hline Architect & Object & $\begin{array}{l}\text { Structures and Joints Described in the } \\
\text { Article }\end{array}$ & Inspirations \\
\hline & $\begin{array}{l}\text { Transitional Cathedral in } \\
\text { Christchurch New } \\
\text { Zealand (2011) }\end{array}$ & $\begin{array}{c}\text { Impregnated paper tubes are connected } \\
\text { with wooden joints in a structure that is } \\
\text { similar to that of the Takatori Catholic } \\
\text { Church }\end{array}$ & $\begin{array}{c}\text { A new, cheap and lightweight } \\
\text { material for low objects in } \\
\text { seismic areas }\end{array}$ \\
\hline & $\begin{array}{l}\text { Tamedia Office Building in } \\
\text { Zurich (2013) }\end{array}$ & $\begin{array}{l}\text { The whole seven-story wooden structure } \\
\text { is connected with the roof, creating a } \\
\text { kind of truss }\end{array}$ & $\begin{array}{l}\text { The main joints look like huge } \\
\text { wooden hinges trough the } \\
\text { mortis, and their role is } \\
\text { similar to that of the tongs } \\
\text { that embrace the construction } \\
\text { posts }\end{array}$ \\
\hline & Aspen Art Museum (2014) & $\begin{array}{l}\text { The openwork cuboid is covered with a } \\
\text { prefabricated truss structure }\end{array}$ & $\begin{array}{l}\text { The curved trusses create the } \\
\text { original, spatial structure of } \\
\text { the ceiling }\end{array}$ \\
\hline & $\begin{array}{l}\text { Multi-functional complex } \\
\text { (2019) in Biel Switzerland }\end{array}$ & $\begin{array}{l}\text { The roofing structure }(240 \times 35 \mathrm{~m}) \text {, in the } \\
\text { form of long-span box beams, is made } \\
\text { from arched girders stiffened with } \\
\text { purlins }\end{array}$ & $\begin{array}{l}\text { Organic construction in the } \\
\text { shape of a huge snake }\end{array}$ \\
\hline & $\begin{array}{l}\text { Terrace House 19-storey } \\
\text { residential tower in } \\
\text { Vancouver; under } \\
\text { construction }\end{array}$ & $\begin{array}{l}\text { Is also referred to as the Hybrid Wood } \\
\text { Tower, which consists of concrete } \\
\text { foundation, a concrete and steel core and } \\
\text { an original timber structure }\end{array}$ & $\begin{array}{c}\text { The Terrace House owes its } \\
\text { name to closed green terraces } \\
\text { with sliding glass panels }\end{array}$ \\
\hline
\end{tabular}

\section{Wooden Joints: A Historical Background}

Archaeological research conducted in the south of Sweden, Germany, England, the Czech Republic, Austria, Poland and Lithuania, enabled the remains of wooden post-andplank structures to be dated to the turn of the Bronze and Iron Ages. For example, in Balbridie village in eastern Scotland, a log house of impressive size $(26 \mathrm{~m} \times 13 \mathrm{~m})$, dating back to 3500-4000 B.C., was excavated. The oldest known log houses in Cambridgeshire were built between 1000 and 800 B.C. (Gerner 2002, p. 63).

The Lusatian culture settlement in Biskupin, discovered in 1933, has been dated to 747-722 B.C.: “The old settlement comprised about 100 houses (erected in post plank construction) of the same size lining eleven parallel streets" (Arlet 2004, p. 198). The characteristic elements of this wooden construction include the horizontal beams inserted in the grooves of the pillars.

Archaeological research also revealed timber houses with braided fillings from the 9 th century and log timber houses dating back to the 10th century. They were constructed from hard wood with the use of pin or wedge joints (Jasieńko et al. 2014, p. 58). The oldest log timber buildings in Switzerland include two houses located in the Schwyz canton: the Nideröst house residential house built at some time between 1176 and 1315, located near the Aegerisee, which was moved to the Sattel community (Available online: www.Morgarten2015.ch, accessed on 2 January 2021).

Timber frame structures were popular in the Early Middle Ages. The oldest ones can still be seen in Germany, England, Switzerland, France, and Poland. About 1200 houses with a half-timbered structure can still be found in Quedlinburg today. One example of a well-preserved building is a two-story house at Wordgasse 3, which was erected in 1346 (Gerner 1994, p. 15). The presented examples clearly prove the durability of wood as a building material.

Structural elements were connected with mortise and tenon carpentry joints, which were reinforced with wooden pegs. The oldest mortise and tenon joints date back to the turn of the 9th and 10th centuries (Jasieńko et al. 2014, p. 58). Carpenter's marks placed 
next to complex joints facilitated the assembly of previously prepared structures ((Tajchman and Jurecki 2020, pp. 190-96) (Schaaf 2005).

Appropriately shaped carpentry joints ensured the transfer of structural loads not only after construction but also after dismounting and reassembly, in the event of renovation or maintenance works ((Tajchman and Jurecki 2020, pp. 199-205). An example that perfectly illustrates this desirable property was the transport of a stavkirke church from the turn of the 12th and 13th centuries from the village Vang in southern Norway and its reassembly in 1844 in Karpacz.

Other historical timber structures that deserve attention include a series of objects, such as bridges: Kapellbrucke in Lucerne (the oldest preserved truss bridge), built in 1333, with an original length of $270 \mathrm{~m}$ (Figure 1a,b), and the Rhinebridge in Schaffhausen from 1758 with an impressive single-span structure (Gerner 2002, p. 74).

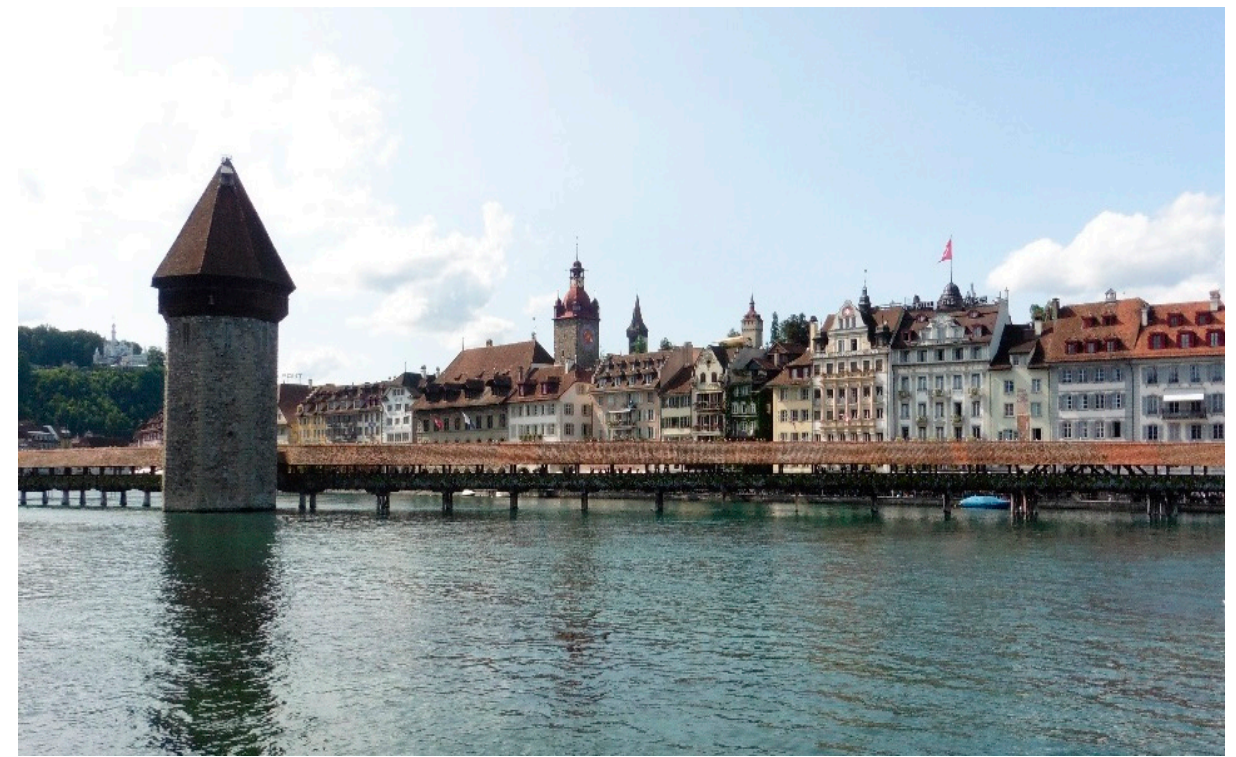

(a)

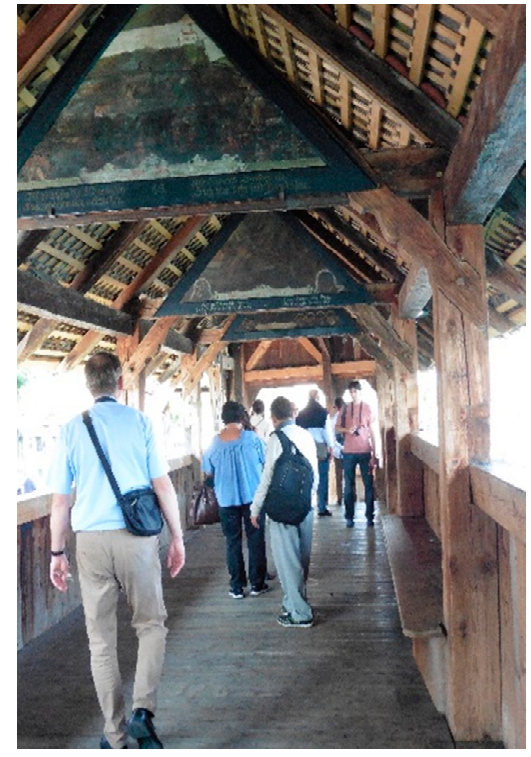

(b)

Figure 1. (a,b) Kapellbrucke in Lucerne: view and roofing detail; photo: Joanna Arlet.

In timber frame structures, the ground beams were: “( . . ) joined in the corners by a finger lap joint (known also as the Tyrolean lap joint) with a half lap joint with pegs or a French lap joint; - intermediateposts were joined with the ground beam by means of a simple tenon, whereas the corner pillars were joined with side tenons (teased);" (Jasieńko et al. 2014, p. 6). The timber frame structure required stiffening diagonal elements: braces to support the corners or angle braces connecting the post to the capping or bolt. These elements were usually connected with diagonal tenons or dovetail joints. However, in some of the buildings, there are no such reinforcements. The simplest form of the brace is an element that connects the sill beam diagonally to the capping, which crosses two or three fields. These elements were then developed into K-shaped braces or decorative braces shaped similar to the Cross of St. Andrew. Characteristic structures in the form of $\mathrm{H}$-frames and special mortise and extended tenon joints were used in Danish vernacular timber buildings (Arlet 2006); (Arlet 2012, p. 258) (Figure 2b). 


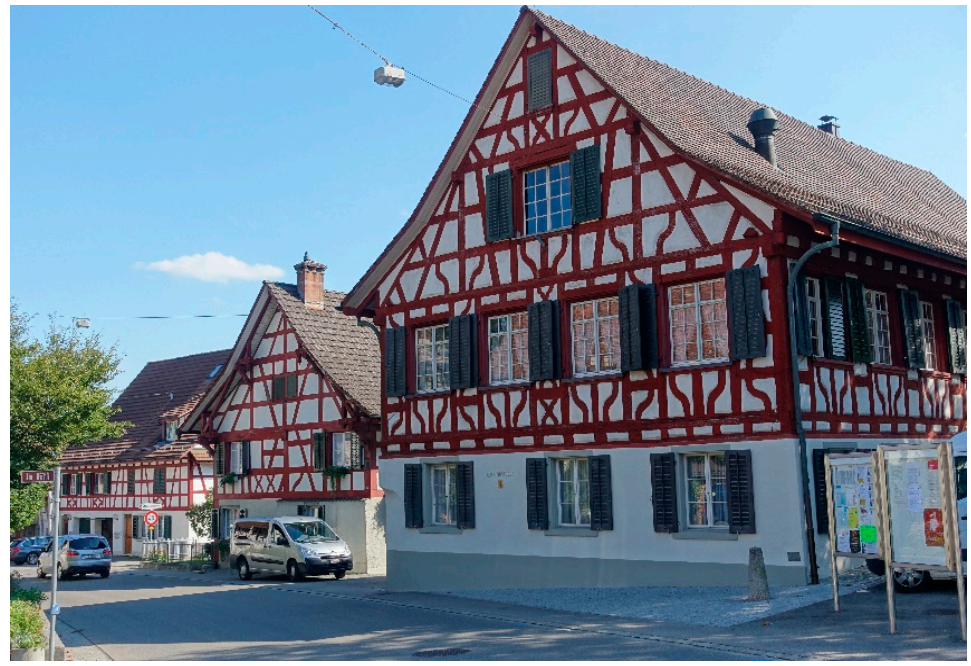

(a)

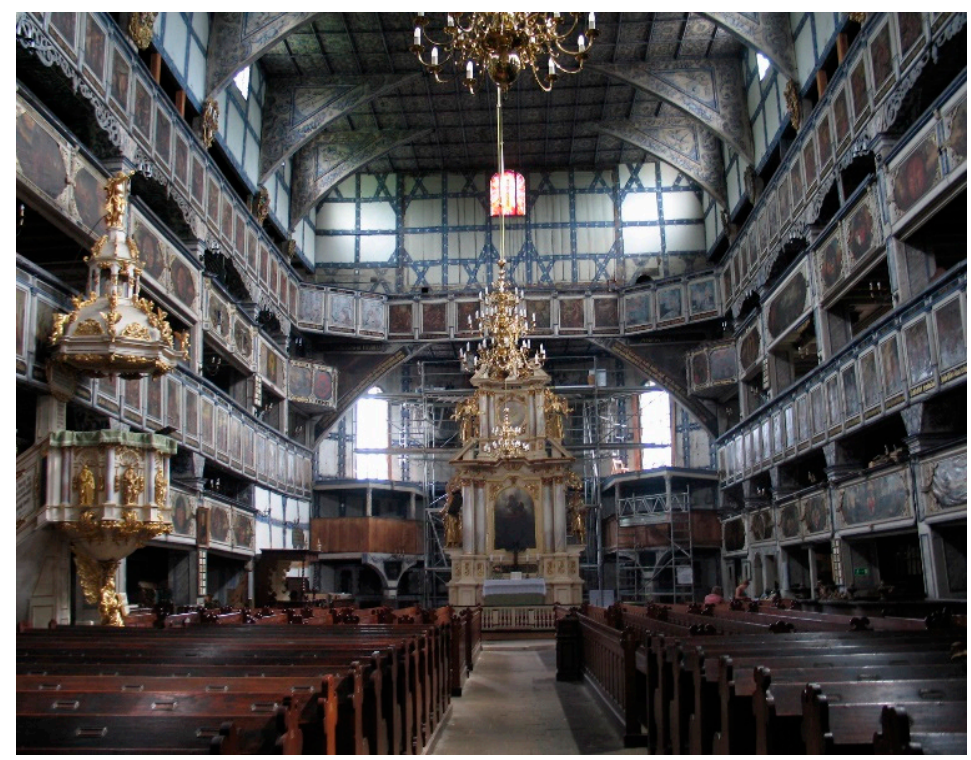

(c)

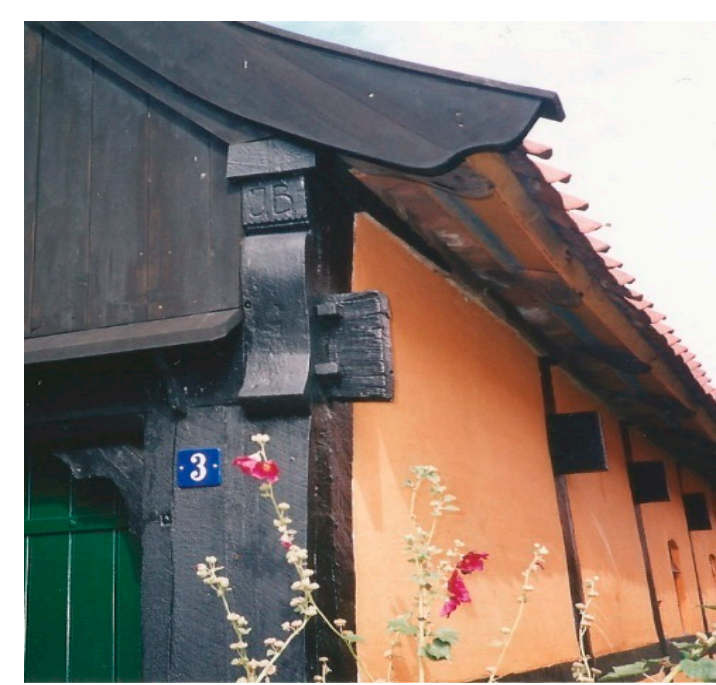

(b)

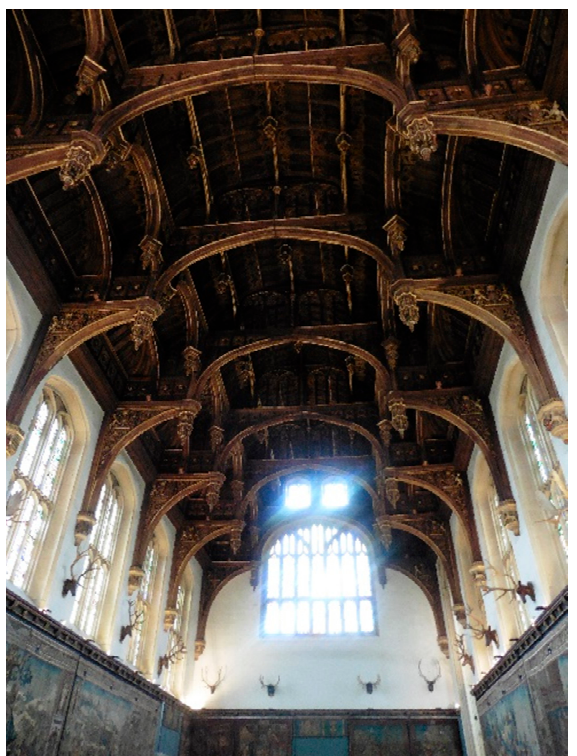

(d)

Figure 2. (a) Half-timbered buildings in the Swiss village Marthalen; photo: Joanna Arlet; (b) Svaneke (Bornholm) building with characteristic mortise and extended tenon joints; photo: Joanna Arlet; (c) rich ornaments inside the Church of Peace in Jawor; photo: Joanna Arlet; (d) Hampton Court Palace, Great Hall; photo: Joanna Arlet.

The essential factor in the development of carpentry techniques in Europe was the popularization of mortise and tenon joints in the 15th and 16th centuries. These joints were used in ancient times in stonemasonry, shipbuilding, and carpentry. These joints, together with the previously used dovetail joints (in Europe, the dovetail joint is often called the swallowtail joint) and halved lap joints, were the main system of structural connections in half-timbered objects (Arlet 2004, p. 25). The advantages of these joints include durability and aesthetic value, as the visible elements of the joints were meticulously decorated with ornamental characteristics for a given region and often polychrome (Gerner 1994, pp. 35-37) (Figure 2a). High-quality woodwork and carpentry were a sign of the owners' position in society, and they now bear witness to the skills of historic craftsmen. Sometimes, the creators, who were proud of their work, signed them.

Buildings characterized by high artistic value are the Churches of Peace, which were erected after the Peace of Westphalia in Lower Silesia: in Jawor in 1655 (Figure 2c) and in Świdnica in 1657. They were designed by the Wroclaw architect Albrecht von Saebisch. What makes the churches unique are rich ornaments, polychromes, and the fact that they 
are among the largest objects with a half-timbered structure (Schaaf 2005). Their age and dimensions prove the durability of wooden structures and their possibilities.

The oldest, archaic systems of roofing over human dwellings were roofs with a transom bar supported by two forked plows, which later evolved into rafter structures, which: “( . . ) were constructed in North-Eastern Europe and in the Alps" (Arlet 2004, p. 21). However, in traditional buildings in Europe, most of the roofing is mainly rafter and collar girders. The most complex, even sophisticated, roof trusses were used in sacral and residential buildings. Thanks to the high quality of wood and careful woodwork craftsmanship, well-preserved king-post trusses and hanger trusses can still be found in numerous European countries.

Historical half-timbered structures in England have steeply pitched gable roofs that were built during the reign of the Tudors. The original structures were elaborately ornamented half-timbered frameworks and hammerbeam ceilings with carved corbels (Figure 2d). These types of constructions were strengthened at the corners with braces. The carpenters who built them had to be well qualified and have excellent skills.

The wooden architecture of Japan and China has a long tradition. The wooden architecture of China, however, is less well known. A significant element of the Chinese building tradition is the system of interlocking wooden dougong supports (known since 770 BC). Taoism and Buddhism also had a valid influence on Chinese architecture. One of the oldest Buddhist temples in China is the Foguang Temple on Wut'ai Mountain (Sickman and Soper 1984, pp. 414-27). The East Main Hall, built in the 9th century, has survived since the Tang Dynasty. The fifty-three monasteries on Mount Wut'ai, built over the centuries, provide a strong representation of the development of Buddhist architecture in China.

An important aspect of Japanese culture and architecture is respect for nature, as well as the fact that the basic building material for centuries has been wood. Significant manifestations of Japanese culture and architecture date back to around the 3rd century A.D. At that time, the temple of the sun goddess Amaterasu was built in Ise. The temple is accompanied by a complex of Great Shrines.

Buddhism reached Japan in the first half of the 6th century. The influence of Buddhism initiated the influence of Chinese architecture and art, through Korean artists and artisans. One of the oldest Buddhist temples is the Horyuji Temple in Nara Prefecture, erected in 607. On the right side of the main axis, there is the Main Hall, named Kondo (the weight of the large, bent roof of the Kondo, bent at the corners, rests on a complex system of rafters, beams and pillars), and on the left is situated the five-story Pagoda, supported on a square platform, in the center of which is a huge wooden pillar. The successive stories of the pagoda symbolize ever higher levels of spiritual perfection (Albertowa 1987, pp. 26-32).

The fact that traditional wooden vernacular architecture and high architecture are important sources of inspiration for contemporary architects and artists will be demonstrated in the following chapters.

\section{Solutions and Technologies That Led to the Growing Popularity of Wooden Structures in the 21st Century}

Wood is one of the oldest materials used by humankind. The examples presented in Chapter 3, Wooden joint: A historical background, draw attention to the variety of solutions, narrowed down to selected objects, mainly from Europe, Japan and China. Wood is a renewable and easy-to-process material. Other advantages include its lightness and strength properties. Moreover, wooden surfaces are not only warm to the touch, but also perceived as warm.

Timber construction systems that are based both on local traditions and on American or Canadian solutions are being continually created and improved.

The use of glued laminated timber has largely contributed to the development of timber construction and has opened many opportunities. This product is light and still has all of the advantages of wood, while the disadvantages are eliminated. Special coatings protect glued wood against humidity, salt, acids, and even fire. The structural parameters of 
glued laminated wood and its resistance to biological corrosion have improved significantly (Arlet 2005, p. 104). These factors contributed to the creation of numerous objects made from glued laminated wood with varying functions, forms, and scales. The next step was to apply acetylated wood technology, patented in the 1930s, on a large scale. The wood became stronger and more resistant to moisture, insects and fungi. Even softwood can be durable, when " $(. .$.$) it has been treated with heat, pressure and a chemical called acetic$ anhydride that vasty reduces the wood's permeability to water and thus its propensity to rot" (Dent and Sherr 2014, p. 58). The above-mentioned factors and the fact that wood is a renewable material contributed to the dynamic growth of interest in wood as a building material.

The changes in the technology of timber structure joints have also been noted. Popular systems of connecting wooden elements with the use of dowel-type connectors, truss connector plates, or metal post anchors are easier to construct and significantly cheaper.

However, contemporary objects with timber structures that successfully employ historic or modified structures and carpentry joints prove that their application is not only possible, but also reasonable. We can also observe changes in wooden joints. The finger joint (a modified dovetail joint) is a relatively new innovation and allows us to obtain a very long wooden element. In order for the strength of such an element to be high, the wood is carefully sorted, and knots and wood damage are removed. This allows for the creation of structures not only with large spans, but also with complicated shapes.

The remarkable research and publications by Professor Gerhard Schickhofer from the University of Technology in Graz (Jabłoński 2019) (Available online: https:/ / www.drewno. $\mathrm{pl} /$ artykuly/11410, accessed on 12 December 2019) have been an important contribution to the development of cross-laminated timber (CLT) technology. A construction material was created, whose high bearing capacity, resistance to humidity fluctuations, light weight, and prefabrication possibility allowed multi-story wood buildings to be erected throughout the world. This structure resembles the timber foundation in the form of cross-laid logs known from the Bryggen district of Bergen, Norway (Paszkowski and Arlet 2004, p. 164). One of the first buildings to make comprehensive use of cross-laminated timber panels (CLT) was an apartment building_Stadthaus Murray Grove (2009) in London—designed by Waugh Thistleton Architects (Dent and Sherr 2014, p. 86).

\subsection{High-Rise Hybrid Timber Buildings}

Until 2018, the highest building with a wooden structure was the 18-floor Tallwood House in Vancouver, designed by Acton Ostry Architects. It is $53 \mathrm{~m}$ tall. Treet or The Tree building in Bergen, designed by Artec, is slightly lower, yet a large part of its structure is made from wood (Schittich 2015, p. 48). The $85.4 \mathrm{~m}$ tall, 18-floor skyscraper Mjøsa Tower was built in 2019 in Brumunddal in Norway. It was designed by Voll Arkitekter. In the same year, the construction of the 24-story building in Vienna was finished, as well as the 15-floor university campus Arbo in Rotkreuz, Switzerland.

Skyscrapers and whole residential estates with timber structures are being designed in Sweden, which is rich in forests. The design of a 40-floor skyscraper-the Trätoppen, presented in 2016 by Anders Berensson Architects-is a unique proposal for Stockholm. The high-rise building was designed using Cross-laminated timber technology and was mounted on top of The Parkaden, a six-story parking lot (designed by Hans Asplund in 1964). Visualizations show a slender skyscraper with wooden sun protection panels and unique details in the form of large digits. It was inspired by a detail of The Parkaden. A 40-story high-rise building in Vancouver, designed by CEI architects, will have a similar height (Schittich 2015, p. 48).

In the high-rise buildings mentioned above, the dominant material in the wood frame structure is cross-laminated timber, while steel and concrete structures (foundations, underground parking lots, and communication shafts) are used sparsely. However, the race to design the tallest wood frame construction building has only just begun. 
Thus, not only the functions, forms, technologies, or joints are changing: the scale of wooden structures is also evolving. In 2019, architects from the MVRDV studio designed the largest timber building in the world $\left(155,000 \mathrm{~m}^{2}\right)$ as the headquarters of the Gazprom Neft company on Okhta Cape in St. Petersburg (Available online: https:/ /www.mvrdv.nl/ projects/422/timber-headquarters, accessed on 24 May 2021).

\subsection{Original Structures of Coverings and Exhibition Pavilions}

Innovative carpentry and hybrid connections can also be observed in objects of a varied functions and scales. A surprising, organic form is the hallmark of the Metropol Parasol at the Plaza de la Encarnación in Seville (Jodidio 2011, p. 18; Jodidio 2015, pp. 374-81). The main designer was Jürgen Mayer, an architect from the J. Mayer H. studio in Berlin. This openwork long-span box beam structure (with a modified half-lap joint), which is $150 \mathrm{~m}$ long, $70 \mathrm{~m}$ wide, and $28 \mathrm{~m}$ tall, was constructed in the year 2011 from cross-laminated timber. Its impressive dimensions make it one of the largest wooden structures in the world. Due to its unique shape, local residents nicknamed it Las Setas. Sculptural forms that resemble mushroom caps are supported by six reinforced concrete posts that also contain vertical communication shafts and fittings and are on steel structures inspired by the design of an umbrella (Figure 3a). They were the basis on which the wooden structure was mounted. An article about the realization of the Metropol Parasol by Carlos Marmol was published on the website Dario de Sevilla on 10 February 2010, entitled Un proyecto imposible.

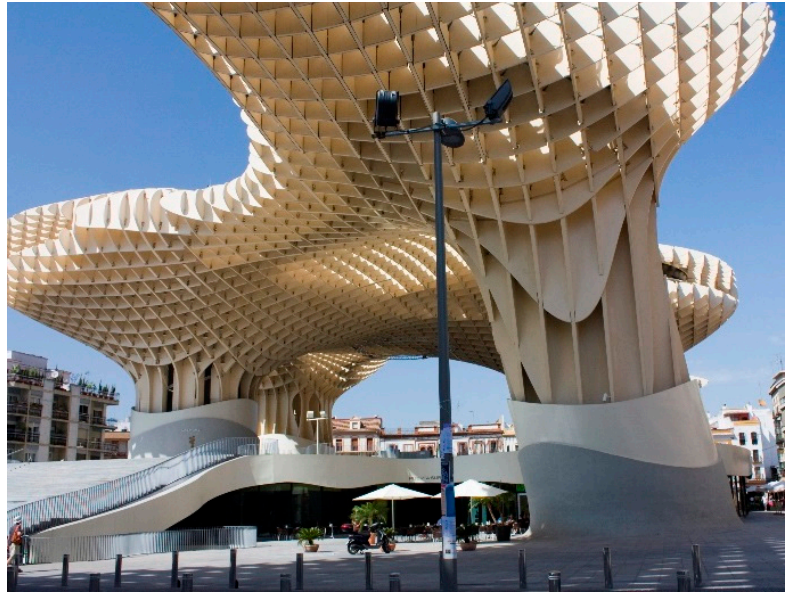

(a)

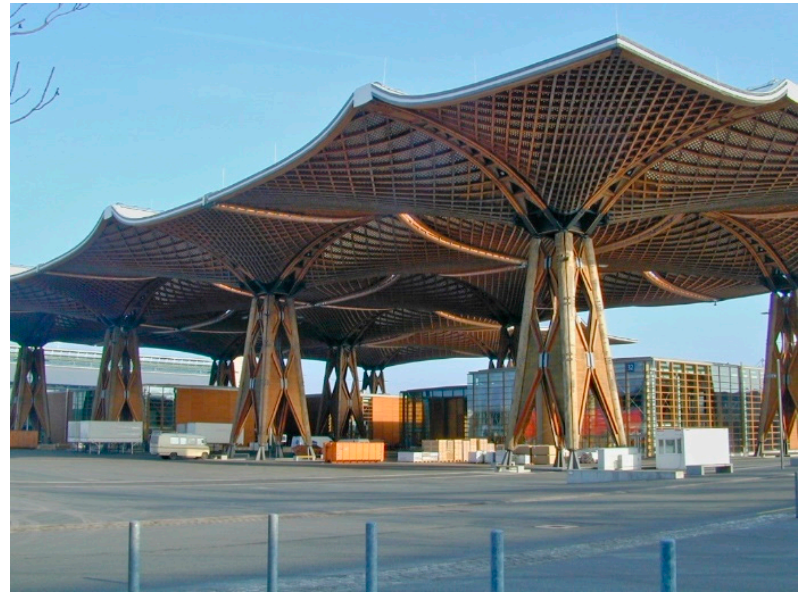

(b)

Figure 3. (a) Seville, Metropol Parasol; photo: Daniel Villafruela; source: Wikimedia Commons; (b) The Expo Roof, Hannover; architect: Thomas Herzog; photo: Harald Bischoff; source: Wikimedia Commons.

At Expo exhibitions, national pavilions are created with impressive, often wooden structures: "Progress was driven by the technological race between industrialized countries. Pavilions in the history of World Expositions introduced a number of innovations related to form, structure, materials and aesthetics" (Krotowski 2018), (Available online: https:/ /www.repozytorium.biblos.pk.edu.pl/redo/resources/41611/file/suwFiles / KrotowskiT_Architecture_Expo.pdf, p. 52, accessed on 15 July 2021). World exhibitions have inspired interesting pavilion solutions that have caught the eyes of audiences.

The Expo Roof (Expo 2000 in Hanover), designed by Thomas Herzog (Gerner 2002, pp. 52-54; Slavid 2005, pp. 136-39), consisted of an enormous $\left(1600 \mathrm{~m}^{2}\right)$ L-shaped freestanding wooden roof. It covered the central meeting point at the World fair, as well as four adjacent pavilions. The innovative structure from cross-laminated timber consisted of 12 "shells" supported by high towers and massive posts. The towers were constructed from tree trunks and triangular panels with steel pins (Figure 3b). The possibilities of shaping complex and original wooden structure forms were expanded once more. 
The Swiss Sound Pavilion, by Peter Zumthor, was presented at the same exhibition (Slavid 2005, pp. 56-59). The wooden beams used in the construction of the pavilion were tied together with strips and arranged in a pile pattern. Only the walls were connected with steel tendons. For these reasons, the wooden elements were not damaged and could also be used after being disassembled.

The Chinese traditions of wooden architecture (including dougong posts) were the inspiration for the architect He Jingang in the China Pavilion (named Oriental Crown) at the Shanghai Expo 2010. Due to the dimensions of the object (converted to China Art Museum), apart from the wooden structure, reinforced concrete foundation posts and steel structure elements were also used.

The designers of the Polish pavilion (WWAA; Marcin Mostafa and Natalia Paszkowska) at the Shanghai Expo drew inspiration from Polish folk art. The main motif of the glued timber covering, which was identical to the façade, was traditional folk-art paper cut-outs: "The unconventionality of the envelope often results from the lack of difference between the façade and the roof, creating a homogeneous "skin" or a "package" for the object" (Krotowski 2018) (Available online: https:/ / www.repozytorium.biblos.pk.edu.pl/redo/ resources/41611/file/suwFiles/KrotowskiT_Architecture_Expo.pdf, p. 55, accessed on 15 July 2021). Another advantage of the openwork covering of the pavilion was the colored light that changed its perception. Inside, the same pattern was further transformed into greenery, a city plan, an industry map, and a suggestive background for the story of the country and its achievements.

Another original structure was the French pavilion at the Expo Milano 2015, designed by XTU Architects. The main element of the form was the wooden roof, with an interior that was to play the symbolic role of a "market hall". Curved structural beams made from cross-laminated timber, growing out of bundles of massive pillars (mounted on steel pins), formed coffers on the ceiling that were connected with cross-notched joints. According to the perception of the authors, the geometry of the wooden ceiling was a reflection of the "hilly" landscape of France. Its expression was enhanced by the oversized, massive wooden structure.

\section{Selected Examples of Contemporary Wooden Frame Buildings}

The noticeable trend of erecting environmentally friendly buildings using timberframed structures is also driven by the designs of outstanding architects. The presented objects have been carefully selected and verified in compliance with the applicable research program in terms of the timber structures and joints used. It is worth considering the innovative examples of wooden architecture designed by Imre Makovecz, Renzo Piano, Kengo Kuma and Shigeru Ban.

\subsection{Imre Makovecz}

Imre Makovecz (1935-2011), a Hungarian architect representing the school of organic architecture, designed original objects inspired by vernacular buildings (Chmielewski 2017, p. 209) (Figure 4a). The works of Makovecz reveal his fascination with Hungarian folklore and tradition. An analysis of the structures used by this architect reveals that they are quite diverse. Imre Makovecz often used timber structures or combined them with reinforced concrete, which he created in a free, sculpture-like manner. The concept of anthropomorphic space first appeared in his work in the Funeral Chapel (1975) at the Farkasrét cemetery in Budapest. The structure of the interior, made of glued wood, is shaped by expressively bent wooden ribs. Curved arches reach down to ground level, but open towards the sculpted exit (Ekler 2012, p. 29). The Lutheran Church in Siófok (1986) also has an anthropomorphic form, because of its entrance, with "winged" doors and eye-shaped windows. The rhythm of wooden rafters and support beams creates a symbolic ark-shaped structure. Through such objects as the Holy Spirit Church in Paks (1987), Stephaneum in Pázmány Péter Catholic University in Piliscsaba (1995), or the main hall of the Áprád Vezér Grammar School, Makovecz drew from the tradition of medieval 
king-post roof trusses (Figure 3b). However, in large-span structures, we notice that the architects use steel elements, including sheet metal, screws, and bolts.

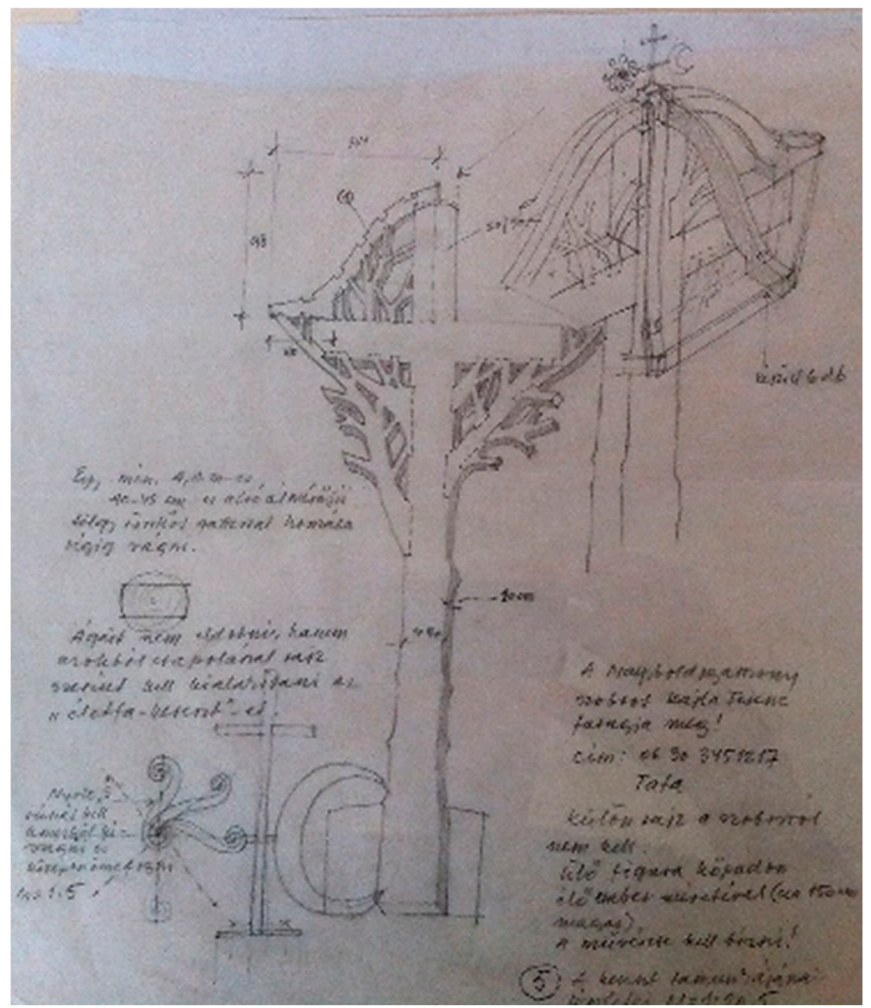

(a)

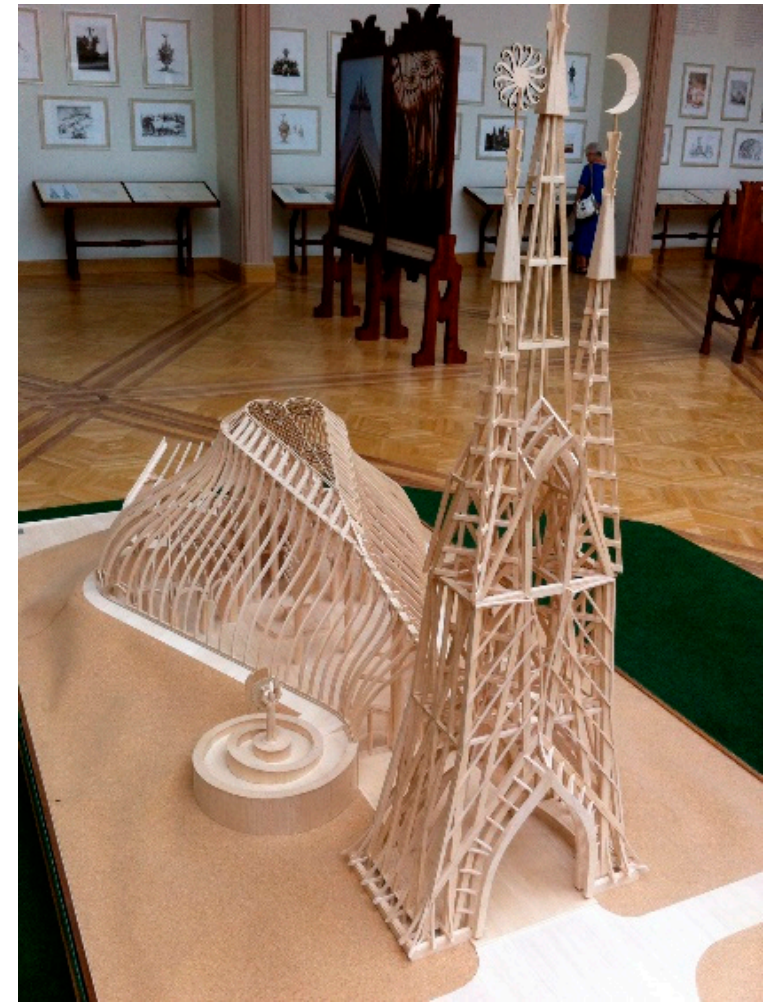

(b)

Figure 4. (a) Drawings by Imre Makovecz; photo: Leszek Świątek; (b) Model of Holy Spirit Church in Paks; photo: Leszek Świątek.

The Holy Spirit Church in Pax is considered to be one of the most important structures of organic architecture of the 20th century. The nave of the building looks like an upside-down boat while the back of the building resembles a human face. The vertical element is a belfry with an entrance and three high gables (Figure $4 \mathrm{~b}$ ). The Sepsiszentgyörgy funeral chapel (1997) in Romania, presents a picturesque set of forms covered with wooden shingles. Two domes above, two naves of the chapel are contrasted with a tall, sharp tower, decorated with two pairs of wooden wings (Ekler 2012, p. 40).

The external form of the Reformed Church in Cluj-Napoca (2008), due to the towers flanking it, resembles a medieval fortified castle. The internal form, with a dynamic series of wooden ribs linked with a keystone, is characteristic of this church. A picturesque external form with a dynamic series of wooden ribs linked with a keystone is characteristic of the New Reformed Church in Cluj-Napoca (2008) Another realization, the Hungarian Pavilion built for Expo 1992 in Seville, resembles an upturned wooden hull. We can easily distinguish elements that resemble ribbing with the keel, stem, and sternpost; longitudinal elements (stringers); and transverse elements (frames). In addition, the roof was finished with picturesque little towers. This project was the one that brought the architect the fame he deserved.

The ideas of Makovecz were pursued by his followers. Some original examples include the Primary School (designed by Lorinc Csernyus in Csenger in Hungary), and the Pancho Arena stadium (2014), designed by the Hungarian studio Doparum Architects, in line with the concept of the adjacent campus of the Athletics Academy, designed by Imre Makovecz. The object has an exposed, suspended roof truss and a structure resembling tree branches, supported by softly shaped, reinforced concrete pillars. 


\subsection{Renzo Piano}

Renzo Piano (born in 1937), laureate of the Pritzker Prize in 1998, used an innovative wooden structure in the Jean-Marie Tjbaou Cultural Centre in New Caledonia (1998) (Buchanan 2004, pp. 86-117). The ethnographic and cultural center in Numea, designed by this architect, consist of 10 modules, whose form was inspired by traditional Caledonian huts (Chmielewski 2017, pp. 67, 68). The modules were located along the central avenue. Horizontal wooden planks and curved ribs from cross-laminated timber were combined with the wooden structure of the internal façade with the use of steel joints and cables. The skeleton of the outer curtain wall consists of " (...) vertical elements made of impregnated bamboo - the fastest growing and biodegradable building material in the world ( ...)" (Chmielewski 2017, p. 66). As a result, two connected sheaths emerged, which the author described as a Double Skin Structural System (Jodidio 2011, pp. 430-35) (Figure 5a). Such a structure ensures effective protection against wind and sunlight and provides passive ventilation for individual buildings. At the same time, through the spectacular development of its dominant form, it is a clear reference to the Kanak culture.

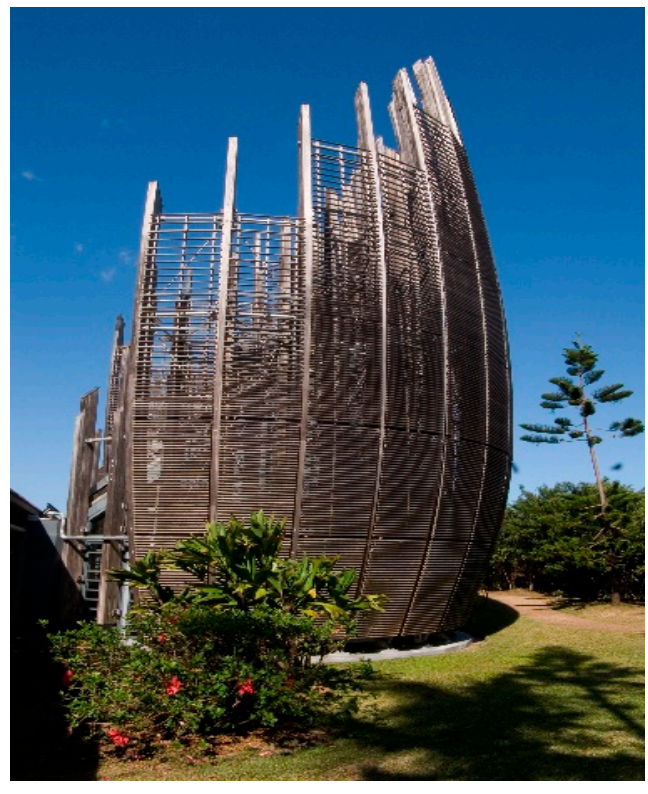

(a)

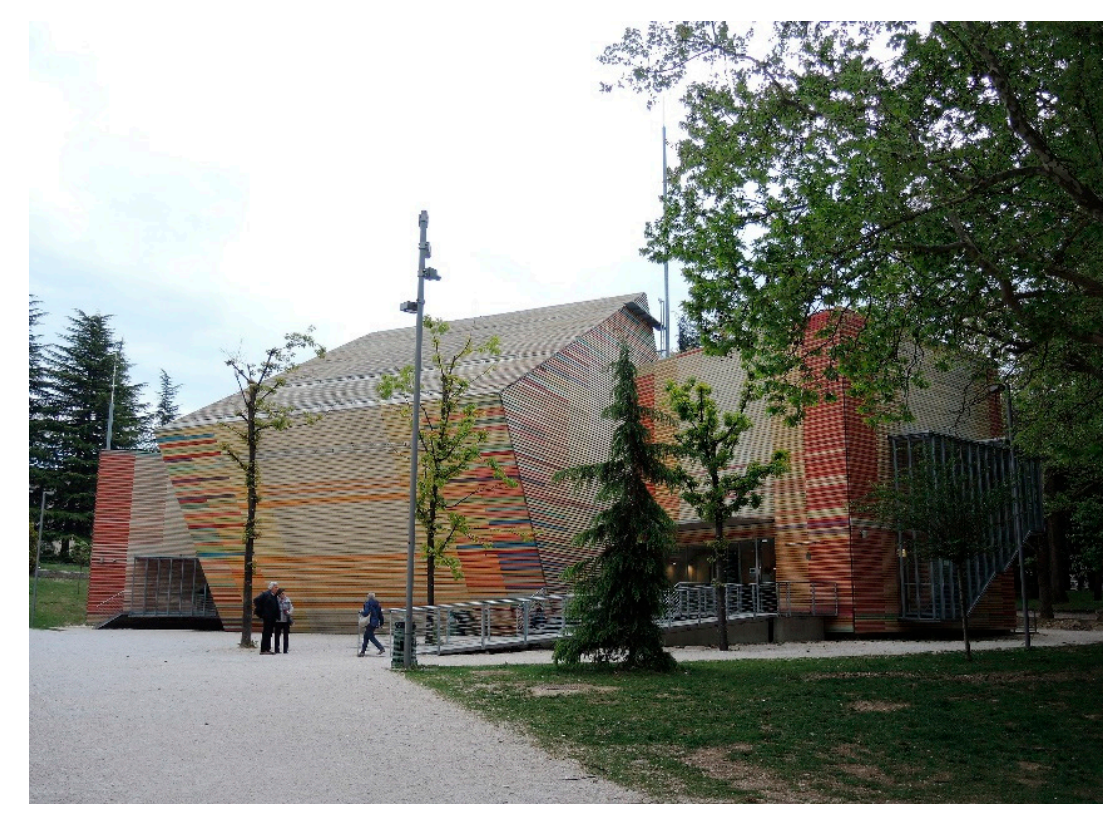

(b)

Figure 5. (a) Jean-Marie Tjibaou Cultural Centre in New Caledonia 1998; architect: Renzo Piano; source: Wikimedia Commons; (b) Auditorium in l'Aquila; architect: Renzo Piano; source: Wikimedia Commons.

The Auditorium in l'Aquila, designed by Renzo Piano for Aquila (in the Province of Trento), which was devastated by an earthquake in 2009, consists of three cubic wooden forms that accommodate an auditorium, a foyer, and a dressing room (Schittich 2015, pp. 104-7) (Figure 5b). The cubes (containing an auditorium, a foyer, and a dressing room), connected with glass corridors, give the impression of a lack of stability, thus referring to the fatal consequences of the earthquake. The effect is enhanced by the different colors of the wooden façade. The wholly prefabricated wooden structure, consisting of a 3D truss and two laminated sheath layers, was named A Flat-Pack Auditorium for L'Aquila (Available online: https://www.archdaily.com/334237/renzo-piano-designs-a-flat-packauditorium-for-laquila/, accessed on 25 May 2021). The connections of the truss, which are hidden from the viewers, were reinforced with a wooden structure connected with metal fittings. Inside the auditorium, "( . . ) suspended acoustic sails consisting of curved timber sheeting, serve the needs of sound diffusion" (Schittich 2015, p. 105).

Appreciation for Renzo Piano's work is evidenced by the first international Spirit of Nature Wood Architecture Award that he received in 2000. 


\subsection{Kengo Kuma}

In 2002, the Spirit of Nature Wood Architecture Award was granted to Kengo Kuma (born in 1954) for the creative use of wood in his work and for his efforts to link architecture to nature. The Toyama Kirari (2015) building in the center of Toyama is home to the Toyama Glass Art Museum, a library, and a bank branch office. The steel and glass façade provides a symbolic reference to the function of the glass museum. The cedar boards, glass and mirrors vertically surround the slanted glass cylinders to create the softly lighted interior. However, both in this object and in the V\&A Dundee Museum (2018), wood mainly plays an ornamental and shielding role.

In the eye-catching building of the Sunny Hills cake shop (2013) in Tokyo, the architect used joints that connect wooden elements at an angle on a large scale (Figure 6b). The way in which they were used and the shape that they form determine the perception of the object. The form of the building resembles an inverted bird's nest or a bamboo basket. These joints were inspired by the Jigoku-Gumi joints as well as the sophisticated Shiguchi joints used in Japanese construction (Sumiyoshi and Matsui 1991, p. 67) (Figure 6a).
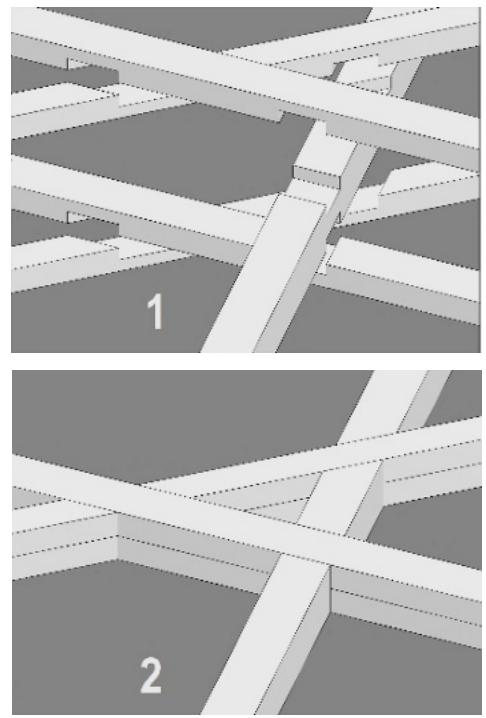

(a)

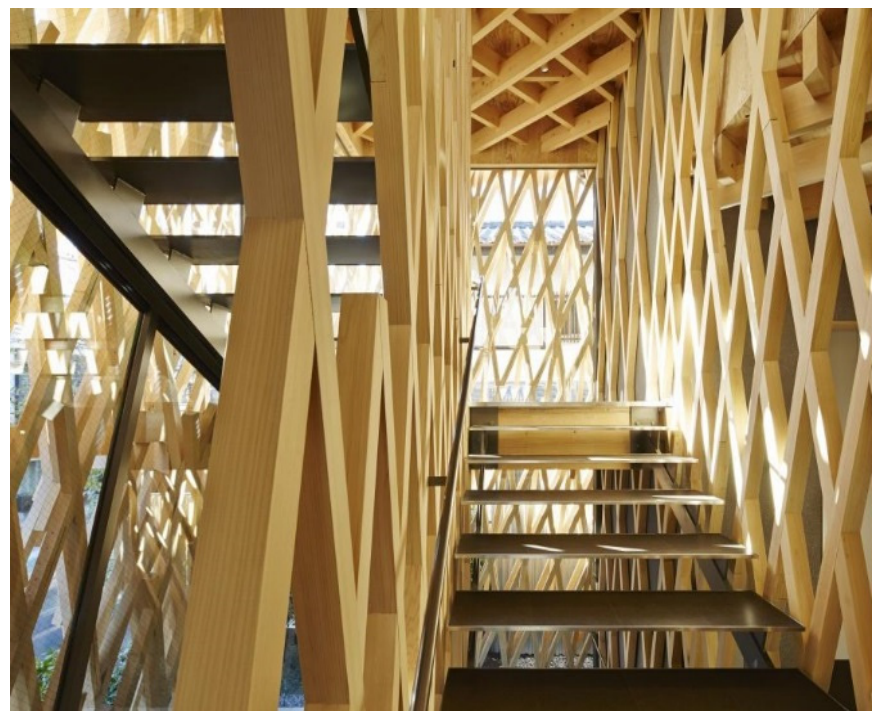

(b)

Figure 6. (a) The Halved Joint Yusuhara Wooden Bridge Museum (2011), by Kengo Kuma drawings: Piotr Arlet; (b) Tokyo, Sunny Hill (2013), Kengo Kuma; source: https://divisare.com/projects/313651-kengo-kuma-and-associates-edwardcaruso-daici-ano-sunnyhill-tokyo-japan (accessed on 6 June 2021).

The system of wooden joints that originate from the Chidori joints (Stamp 2018), which were used in traditional Japanese toys, was applied by Kengo Kuma in the GC Prostho Museum Research Center (2010) in Kasugai (Japan). The multiple connections have created a series of wooden truss structures that play a structural role and are used for the museum exhibition (Jodidio 2015, pp. 310-19) (Figure 7b). 


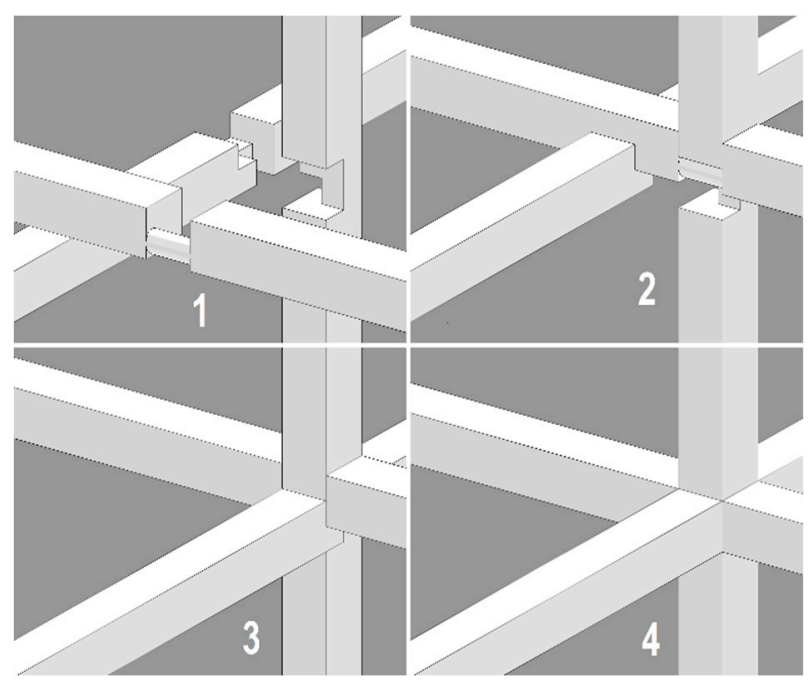

(a)

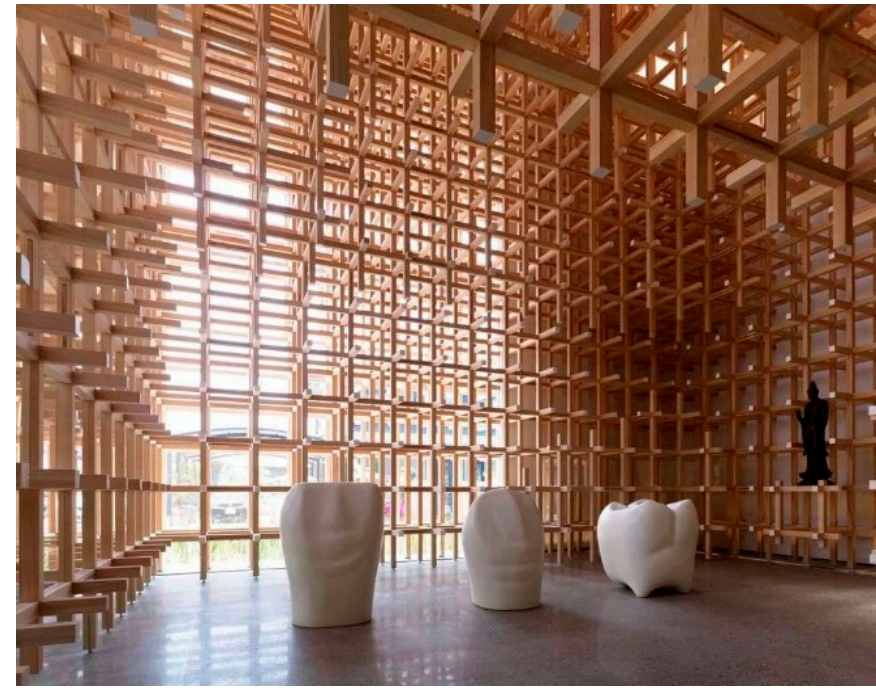

(b)

Figure 7. (a) The Chidori Joint GC Prostho Museum Research Center (2010), by Kengo Kuma; drawings: Piotr Arlet; (b) GC Prostho Museum Research Center; interior, photo: Daici Ano; Source: https:/ /www.archdaily.com/199442/gc-prosthomuseum-research-center-kengo-kuma-associates (accessed on 5 May 2021).

This idea, which allows modules to be connected with the use of the joints presented below, was also employed by the architect in 2011 in the design of Starbucks Coffee in Tokyo. Moreover, he also used modified traditional joints in the design and production of modular furniture, creating the Chidori System (Figure 7a). In this way, Kengo Kuma and his team, in cooperation with local craftsmen, opened up new development opportunities for crafts in the Tōhoku region, heavily damaged by the earthquake and tsunami of 11 March 2011.

In the design of the Yusuhara Wooden Bridge Museum (2011) (Carder et al. 2011) in the city of Yusuhara (on Shikoku island), Kengo Kuma used an innovative structure that he referred to as the Interlocking system. The idea of the project is a "wooden bridge" that connects two public utility buildings located on two sides of a road. The structure consists of a set of supports built from small elements of interlaced beams connected by wooden joints. In this project, Kengo Kuma referred to the traditional, archaic Chinese set of supports called dougong, which ensure a flexible transfer of load along the roof truss (Gerner 2002, p. 120).

These supports, which became increasingly ornamental over time, were used in sacral and public buildings, giving them the characteristic look of a pagoda. This technique, which was used as early as in the 6th century, under the influence of Japanese Buddhism, was "referenced" in this object and used in a way that is innovative yet, at the same time, consistent with the traditional concept of supporting the roof truss on a massive internal support post.

This principle was applied by Kengo Kuma in a similar way in the Cafe, Coeda (2017), a building located on a cliff in the Japanese town of Shizuoka. The structure of the object is supported by a central post in the form of a tree so that the view of the surrounding park and the Pacific Ocean remains undisturbed. In this case, a hybrid structure was used, as the timber frame was reinforced with carbon fiber rods (Gonzales 2017; Available online: https:/ /www.metalocus.es/en/news/cafe-coeda-house-kengo-kuma, accessed on 16 January 2021).

In the Odunpazari Modern Art Museum (2019) in Eskisehir in northwestern Turkey, Kengo Kuma built a set of "wooden crates", both outside and inside. It provides a clear reference to the layout of objects in the nearest surroundings. The architect named the wooden structure, which resembles the log timber structure, Interlocking timber boxes. Interestingly, the wooden elements in the object were joined without using nails or bolts. 
On the other hand, the Bato Hiroshige Museum of Art (2000) has a completely different aesthetic. The structure of the object, supported on a reinforced concrete base, is made from steel combined with cedar wood and covered with wooden blinds and glass panes. Additionally, the whole building is covered with an impregnated cedar roof. The direct inspiration was the woodcuts (ukiyo-e) by the famous artist Hiroshige Ando (1797-1852) (Slavid 2005, pp. 218-21). The perception of his art corresponds to the semi-opaque and transparent planes, which change under the influence of light. In this object, the joints have been intentionally hidden.

In the objects designed by Kengo Kuma, wood does not only play a structural or shielding role. In his designs of buildings, especially interiors, the artist treats wood as an important element in the design and even sculpture. This sublime effect is achieved by using innovative forms and techniques but is also attributable to high quality. Customized joints, meticulously created from opulent wood, are, in this case, works of art.

\subsection{Shigeru Ban}

The Japanese architect Shigeru Ban (born in 1957) received the Pritzker Award in 2014 for his innovative use of materials, as well as for conducting humanitarian activities on a wide scale (Architecture Pritzker Prize 2014).

It is worth noting, in the works of Shigeru Ban, the use of wood as an innovative construction material and the unconventional application of impregnated paper tubes connected with wooden joints in the construction of his designs. Excellent examples of such structures include the Takatori Catholic Church in Nagata-ku, which Kobe built to replace the church that had been destroyed by an earthquake in 1995, and the Transitional Cathedral in Christchurch, New Zealand, also named the Cardboard Cathedral, in place of the cathedral that was destroyed in 2011. The high, gabled roof of the church consists of 86 cardboard tubes (Figure 8a).

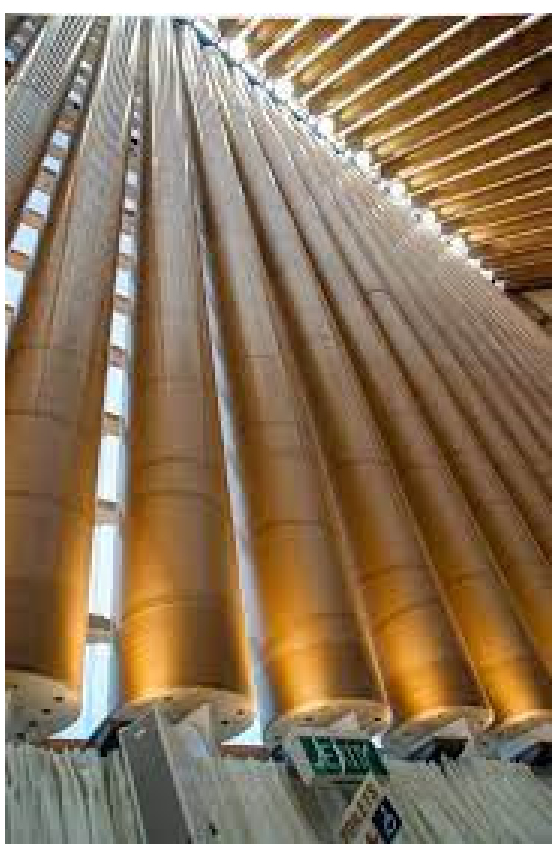

(a)

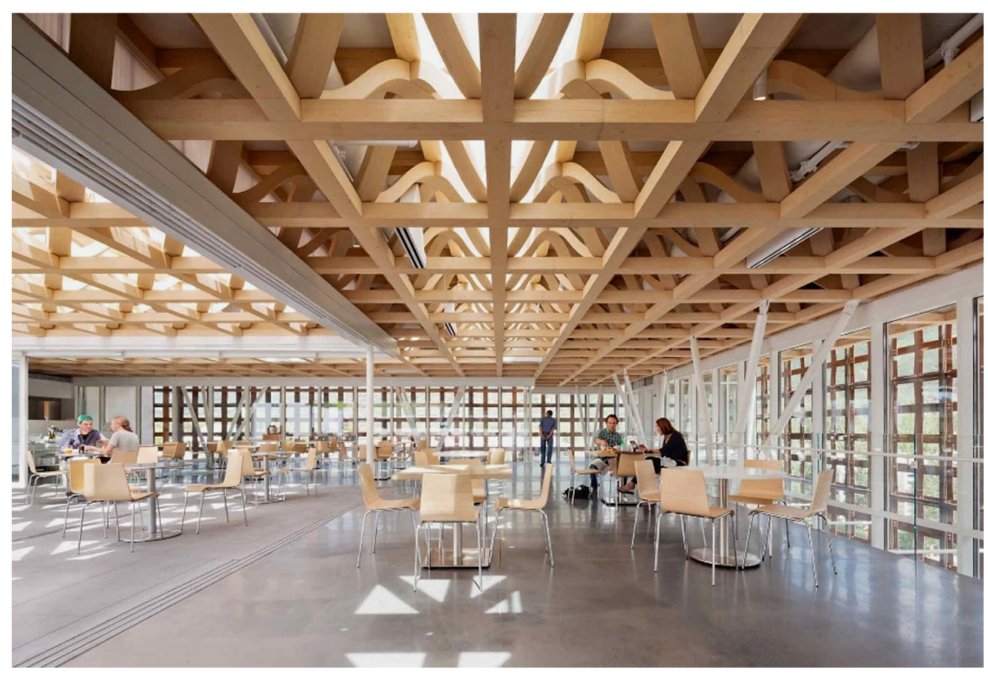

(b)

Figure 8. (a) Transitional Cathedral in Christchurch, New Zealand; architect: Shigeru Ban; photo: Jocelyn Kinghorn; source: Wikimedia Commons; (b) Aspen Art Museum (2012-2014); photo: Michael Moran/OTTO; source: https: / www.archdaily.com/546446/aspen-art-museum-shigeru-ban-architects/540f87e0c07a803fb300003e-aspenart-museum-shigeru-ban-architects-photo (accessed on 5 May 2021).

Another original structure is the Nine Bridges Country Club (2006-2009), designed by Shigeru Ban in South Korea (Jodidio 2011, pp. 90-93). The object consists of three buildings 
of different structures: the main building of the golf club, the VIP zone, and the hotel. The main building was inspired by traditional Korean architecture. An interesting solution is the atrium, which is three stories high and consists of a reception lobby, the member's lounge, and a party room. This object consists of 21 bundles of wooden columns that are curved and bent towards the top and create an openwork, organic structure. It resembles the complex mesh of Gothic ceilings and the baroque structure of the St. Lawrence Church in Turin, designed by Guarino Guarini. A similar solution was used by the architect in the design of the Centre Pompidou-Metz (2006-2010) (Jodidio 2015, pp. 86-89; Chmielewski 2017, p. 73). In this project, not only was the structure of the wooden vault based on a hexagonal pattern, but this was also the case for the translucent roof (inspired by a Chinese hat), covering the entire complex (Walker 2014). The spatial construction elements were connected with steel bolts. The similar motif was applied on a much larger scale in the design of the environmentally friendly Long Thanh International Airport (2016) in Vietnam.

The first museum designed by Shigeru Ban in the USA was the Aspen Art Museum (2012-2014), located in the suburbs of Aspen, Colorado. The openwork cuboid is covered with a prefabricated truss structure. The curved trusses create an original, spatial ceiling structure (Walker 2014). Their form and the joints applied mean that the wooden elements may only be connected with long wood screws. Thanks to these solutions, the wooden elements are completely visible, and the external and internal spaces are able to merge. The delicately undulating façade has been transformed into a dynamic cover for the minimalist interior (Available online: https:theplan.it/award-2016-culture/aspen-art-museum, accessed on 10 March 2021). The architect based the spatial wooden structure on bundles of steel supports that are painted white (Figure 8b).

Shigeru Ban perfectly adapted the form of the Terrace House 19-story residential tower in Vancouver (under construction) to match the neighboring Evergreen building. This complex-shaped building was designed in 1980 by Artur Ericson. The Terrace House owes its name to closed green terraces with sliding glass panels. It is also referred to as the Hybrid Wood Tower, which consists of a concrete foundation, a concrete and steel core, and the original timber structure. Due to the innovative, environmentally friendly solutions and the fact that the object is designed to match the work by Ericson, the Terrace House sets a new trend in architecture.

In the Tamedia Office Building in Zurich, erected in 2013, Shigeru Ban used an innovative combination of wood and glass (Schittich 2015, pp. 56-61). The shape and detail of the object, with its sparse form and balanced colors, perfectly match the surroundings and the architectural traditions of the city. The elements that play an important structural but also aesthetic role are the timber structure and the unique joints: "The wooden beams interlock, requiring no metal joints" (Architecture Pritzker Prize 2014) (Available online: https: / / www.pritzkerprize.com/announcement-shigeru-ban, accessed on 16 April 2021). They resemble pin joints or huge wooden hinges (Walker 2014). Furthermore their role is similar to that of tongs that embrace the construction posts (Figure 9a,b). The photo published in ArchDaily (Shigeru Ban Architects 2014) (Available online: https:/ /www.archdaily.com/ 478633/tamedia-office-building-shigeru-ban-architects, accessed on 12 December 2019) allows us to take a peek inside the decorative joint, which is connected with a massive wooden pin and blocked. The whole seven-story wooden structure is connected with the roof, creating a kind of truss that surprises the viewer with its simplicity and the logic of the solutions applied. 


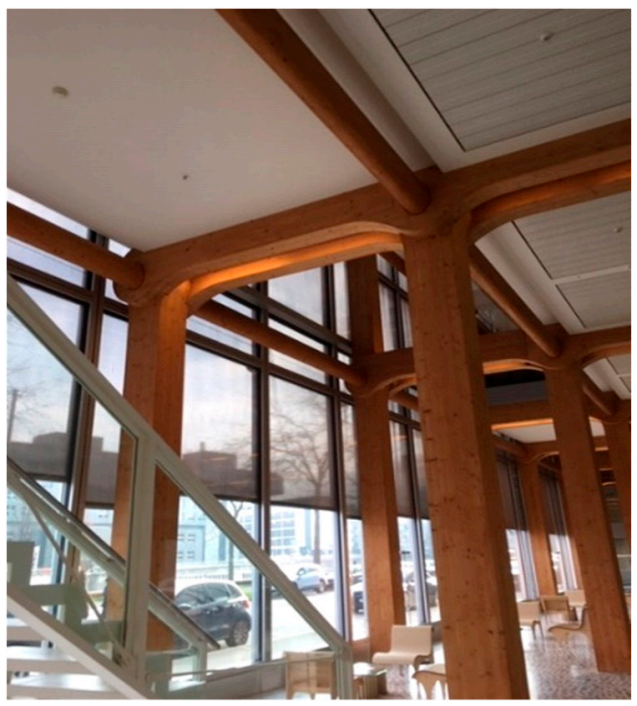

(a)

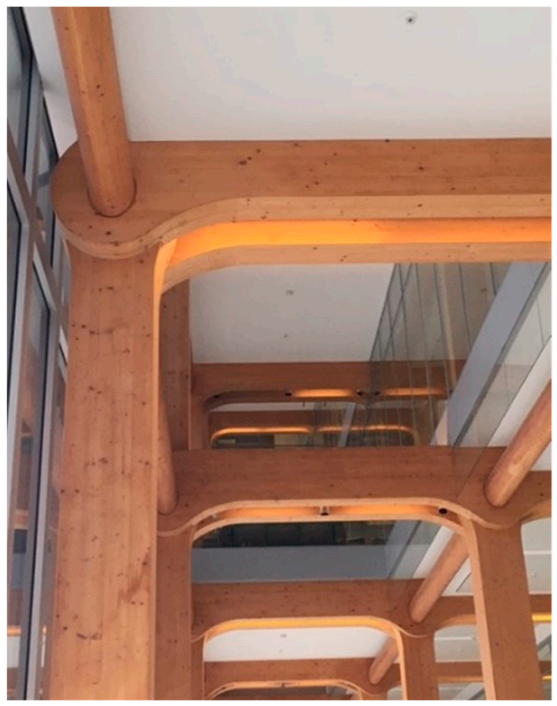

(b)

Figure 9. (a,b) Zurich, Tamedia Office Building; architect: Shigeru Ban; details, photo: Joanna Arlet.

The works of Shigeru Ban not only received the prestigious Pritzker Award but were also appreciated in a series of individual exhibitions that presented his innovative designs and spatial models of the original structures, including the artistic expression of the joints. The exhibition The inventive work of Shigeru Ban at Sherman Contemporary Art Foundation took place in 2017 in Sydney (Shigeru Ban Architects 2017) (Available online: http:/ / www.shigerubanarchitects.com/works/2017_SCAF/index.html, accessed on 10 March 2021).

Biel, situated in the Swiss canton of Bern, is home to the Switzerland Innovation Park Biel/Bienne, which consists of four modern research centers that are closely linked to the industry. In the same city, Shigeru Ban erected a multi-functional complex for the Swatch and Omega company (2019). The inside of the object, which is shaped like an astonishingly giant snake, accommodates, among other spaces, a railway station, a museum, and several conference rooms. Thanks to its investor-friendly conditions and outstanding projects, Biel has become a recognizable and attractive location for new investments. The roofing structure, in the form of long-span box beams, is made from arched girders stiffened with purlins. The object is approximately $240 \mathrm{~m}$ long and $35 \mathrm{~m}$ wide, which makes it one of the largest wooden structures in the world. The final result is enhanced by the contrasting, almost organic external structure.

\section{Discussion}

In 1983, Kenneth Frampton published an article titled Towards a Critical Regionalism: Six Points for an Architecture of Resistance. It was an important attempt to diagnose the problem of globalization processes and architectural unification. Referring to the tradition of the region and the specificity of the place in which a building is designed was one of the methods proposed to avoid the threats posed by this problem.

Empirical research on regional wooden architecture (in north-western Poland, Denmark, southern Norway, southern Sweden and north-eastern Germany) was carried out from 1998 to 2005. The results of this research, which are closely related to the presented article, were published, inter alia, in the article Carpentry joints in West Pomeranian wooden churches (Arlet and Arlet 2003) and the published doctoral dissertation: Wooden half-timber architecture in Western Pomerania, characteristics of form, protection methods and rules pertaining to the continuity of cultural tradition (Arlet 2004).

Research has shown a tendency to move away from traditional structures and connections, in favor of steel connections and the disappearance of traditional carpentry skills. 
On the other hand, at the same time, conservation workshops have been held as part of the Wood Culture program, under the patronage of Europe Heritage. The aim of the programs was to restore forgotten techniques and skills. In 2001, such workshops were held in Romania and Lithuania, and a year later in France, Sweden and Finland (Arlet 2004, pp. 151-52). In 2001, I had the opportunity to co-organize and participate in the international program Safeguarding Historic Waterfront Sites Bryggen in Bergen as a Case (2001-2002) and, in 2005, in Sweden, at the Traditional Craft in 21 Century Architecture program (2004-2005) in Eksjö.

Moreover, the architect Imre Makovecz used traditional patterns and techniques based on Hungarian vernacular wooden architecture, to be an isolated example in Europe at the time.

The situation began to change, along with new materials and technological possibilities. The recently conducted research, supported by a literature review, confirms the growing possibilities of using wood in contemporary architecture (Jodidio 2015, pp. 6-7). Material and technological progress were insightfully considered because "Material making is a new architecture" (Dent and Sherr 2014, p. 16). Research objectives were focused on the use of wooden or hybrid (wood with steel connectors) joints. Due to the scope of the subject, the discussed wooden structures only constituted the background of the considerations. The above-mentioned examples of contemporary wooden architecture, created by outstanding architects, contributed to the dynamic development of modern wooden architecture. The condition for the creation of exposed wooden joints, in accordance with the applicable, restrictive requirements in terms of load-bearing capacity and fire protection or protection against the biological corrosion of wood, resulted in the development of new technologies. A similar point of view was presented by Philip Jodidio: "A selection of about 60 recent structures designed partially or completely in wood may not be sufficient to give real overview of what is happening across the world, but it is clear that wood is very contemporary material, being used in innovative ways that include the very latest technology" (Jodidio 2011, p. 17).

The impulse to use wood as a building material was borne by its plastic and aesthetic qualities, as well as the growing role of ecology and the awareness of the need to protect the climate (wood is a renewable, biodegradable material and has a low carbon impact). A great number of aspects should be taken into account and, aside from the advantages of using wood, we should consider the justifiability of using it on a large scale. An important contribution to the discussion is the article More Timber in Construction: Unanswered Questions and Future Challenges (Hart and Pomponi 2020). The authors considered the effects of a significant increase in the use of structural timber in architecture on the impact on climate change.

The activities of the outstanding architects presented in this study revealed new possibilities for wooden architecture. A number of them referred to the regional traditions, which they creatively transformed into spectacular construction solutions, using original wooden or hybrid carpentry connections. Reaching towards the tradition of the place in which a building is designed is, therefore, an opportunity to diversify the created architecture. However, the question of whether the discussed trends in contemporary wooden architecture will be permanent remains.

\section{Conclusions}

The long-term study of traditional wooden buildings in Poland, northern Germany, Denmark, Sweden, Estonia, Latvia, and Finland, as well as in the south of Norway, reveals the advantages of vernacular timber structures and their potential. These objects are not only light, durable, and relatively cheap but are also very easy to modernize and develop. An important aspect is the fact that wooden structures and carpentry joints can be reused after disassembly for renovation and maintenance work. The joints used in modern timber structures are evolving, because they must meet contemporary challenges, such as durability and safety. 
Research conducted in the 1980s and 1990s led to the conclusion that it would be impossible to avoid the application of steel joints, which are cheaper and easier to install, in modern structural solutions for timber frame buildings. However, this worrying trend was reversed at the turn of the 21st century. The number and quality of erected wooden objects are proof that this is not just a short-lived fad. The designs by famous architects presented here show the new possibilities of using timber structures and new joints (although often inspired by tradition). An indisputable advantage of the presented objects is their originality, both in the aspects of form and structure and in the details used. At the same time, the visible inspirations in their works underline the rich heritage of vernacular architecture. One can notice the huge expressive potential of folk art in the works of Imre Makovecz. Renzo Piano draws from the tradition of places, where he works in an unconventional fashion. The designs of Kengo Kuma and Shigeru Ban surprise us with their focus on embedding newly created objects in the context of their location, which comes from the Japanese mentality of respecting nature. At the same time, the artists creatively use the architectural traditions of the Far East. In this region, wood has been the main material used to build houses, as well as shrines, palaces, and residences, for centuries. This required using the best available materials and employing top-class craftsmen and artists. The examples provided here demonstrate that architectural and artistic traditions may counterbalance the globalization of modern architecture.

Unconventional timber structures include the buildings in Biel (Switzerland) and Seville that are discussed herein. Although it is difficult to find inspiration from traditional vernacular architecture, these forms were included in the study, as they open completely new opportunities for shaping wooden objects.

The specific examples of the latest solutions presented above demonstrate that traditional wooden structures and the carpentry joints employed therein remain a model for outstanding contemporary architects and constructors. In their vision, carpentry joints not only act as structural elements, but also provide artistic effects that are essential for the perception of the works. As a result, both vernacular architecture and contemporary tall wooden structures may continue to inspire us. This noticeable trend offers a chance to bring regional architecture back to life, along with traditions in urban and rural planning, construction, and craftsmanship, as well as object forms, details, and carpentry techniques. Modern, environmentally friendly wooden architecture, which responds to the needs of our time may provide a counterbalance to unified, standardized objects. Additionally, it may also contribute to the development of local craftsmanship.

The presented artists and their works make us aware of new development prospects for timber architecture. In the design process, they often refer to local traditions and genius loci, but-at the same time-they employ new technological and material possibilities. Innovative forms and structures, as well as high-quality finishing, make the architecture created in this way true art.

Funding: This research received no external funding.

Institutional Review Board Statement: Not applicable.

Informed Consent Statement: Not applicable.

Conflicts of Interest: The author declares no conflict of interest.

\section{References}

Albertowa, Zofia. 1987. O Sztuce Japonii. Warszawa: Wydawnictwo Wiedza Powszechna, ISBN 83-214-0178-3.

Architecture Pritzker Prize 2014. Available online: https://www.pritzkerprize.com/announcement-shigeru-ban (accessed on 18 December 2020).

Arlet, Joanna. 2004. Drewniane Budownictwo Szkieletowe na Pomorzu Zachodnim. Szczecin: Wydawnictwo Uczelniane Politechniki Szczecińskiej, ISBN 83-88764-58-6.

Arlet, Joanna. 2004. Biskupin, the Lusatian settlement. In Safeguarding Historic Waterfront Sites Bryggen in Bergen as a Case. Szczecin: Wydawnictwo Walkowska, Szczecin, pp. 196-98, ISBN 83-918558-1-3. 
Arlet, Joanna, and Piotr Arlet. 2003. Złacza Ciesielskie w Zachodniopomorskim Drewnianym Budownictwie Sakralnym. Szczecin: Antikon, pp. 25-32, ISBN 83-91-3544-6-6.

Arlet, Joanna. 2005. Is it possible to continue the tradition of buildings regional forms in Western Pomerania region? In Manifesto Traditional Craft in 21st Century Architecture. Olita-Litwa: Alytus, pp. 101-6, ISBN 91-631-7152-X.

Arlet, Piotr. 2006. Drewniana konstrukcja szkieletowa z ram typu "H” w Niemczech, w Danii i w południowej Szwecji. In Drewno i Materiały Drewnopochodne w Konstrukcjach Budowlanych. Szczecin-Międzyzdroje: Wydawnictwo Uczelniane Politechniki Szczecińskiej, pp. 65-70, ISBN 83-7457-008-3.

Arlet, Piotr. 2012. Architektura Wernakularna Obszaru Morza Battyckiego-Analogie, Różnice, Obraz Ogólny. Szczecin: Wydawnictwo Uczelniane Zachodniopomorskiego Uniwersytetu Technologicznego w Szczecinie, ISBN 978-83-7663-102-8.

Buchanan, Peter. 2004. Renzo Piano Building Workshop. London: Phaidon, ISBN 0714842877.

Carder, Neil, Kristel Derkowski, and Jay Pabila. 2011. Yusuhara Wooden Bridge Museum pdf. Available online: https://www. docplayer.net/54600249-Yusuhara-wooden-bridge-museum.html (accessed on 14 January 2021).

Chmielewski, Wojciech. 2017. Regionalizm Wspótczesnej Architektury Reakcja na Procesy Globalizacji. Kraków: Wydawnictwo PK, ISBN 978-83-7242-930-8.

Dent, Andrew H., and Leslie Sherr. 2014. Material Innovation Architecture. London: Thames \& Hudson, ISBN 978-0-500-29128-3.

Ekler, Dezsö. 2012. Stories by Makovecz. Imre Makovecz 1935-2011. Országépitö 2012/4 Special Edition. pp. 28-43. Available online: https:/ / pdfcoffee.com/ orszagepito-2012-04-angolpdf-pdf-free.html (accessed on 15 October 2020).

Gerner, Manfred. 1994. Fachwerk. Stuttgart: Deutsche Verlags-Anstalt, ISBN 3-421-03053-7.

Gerner, Manfred. 2002. Die Kunst der Zimmerer, Meisterwerke aus Europa, Amerika und Asien, Stuttgart. München: Deutsche VerlagsAnstalt, ISBN 3-421-03287-4.

Gonzales, Teodoro. 2017. Café, Coeda House by Kengo Kuma. Available online: https:/ /www.metalocus.es/en/news/cafe-coedahouse-kengo-kuma (accessed on 16 January 2021).

Hart, Jim, and Francesco Pomponi. 2020. More Timber in Construction: Unanswered Questions and Future Challenges. Available online: https: / www.mdpi.com/2071-1050/12/8/3473 (accessed on 25 July 2021).

Jabłoński, Dominik. 2019. Przemysł Drzewny. Gerhard Schickhofer Tegorocznym Laureatem Nagrody Marcusa Wallenberga. Available online: https:/ / www.drewno.pl/artykuly/11410,gerhard-schickhofer-tegorocznym-laureatem-nagrody-marcusawallenberga.html (accessed on 12 December 2019).

Jasieńko, Jerzy, Tomasz Nowak, and Anna Karolak. 2014. Historyczne złącza ciesielskie/Historical carpentry, joints. Available online: https:/ / repozytorium.biblos.pk.edu.pl/redo/resources/30209/file/suwFiles/JasienkoJ_HistoryczneZlacza.pdf (accessed on 11 July 2019).

Jodidio, Philip. 2011. WOOD Architecture Now! Cologne: Taschen GMBH, ISBN 978-3-8365-2329-5.

Jodidio, Philip. 2015. 100 Contemporary Wood Buildings. Cologne: Taschen GMBH, ISBN 978-3-8365-4281-4.

Krotowski, Tomasz. 2018. Architecture of Expo Pavilions-Beauty or Rationality? Available online: https://www.repozytorium.biblos. pk.edu.pl/redo/resources/41611/file/suwFiles/KrotowskiT_Architecture_Expo.pdf (accessed on 15 July 2021).

Paszkowski, Zbigniew, and Joanna Arlet. 2004. Safeguarding historic waterfront site Bryggen as a complex task. In Safeguarding Historic Waterfront Sites Bryggen in Bergen as a Case. Szczecin: Wydawnictwo Walkowska, pp. 164-68, ISBN 83-918558-1-3.

Schaaf, Ulrich. 2005. Systemy ciesielskich znaków montażowych jako źródło wiedzy o warsztacie ciesielskim i autentycznej substancji zabytku na przykładzie Kościoła Pokoju w Świdnicy. In Zabytkowe Budowle Drewniane i Stolarka Architektoniczna Wobec Wspótczesnych Zagrożeń. Edited by Okoń E. Wydawnictwo. Toruń: Uniwersytetu Mikołaja Kopernika, pp. 113-34.

Schittich, Christian. 2015. Holz Wood Best of Detail. München: Institut für Internationale Architectur-Dokumentation GmbH \&Co. KG, ISBN 978-3-95553-214-7.

Shigeru Ban Architects. 2014. Tamedia Office Building. Zurich: ArchDaily, Available online: https://www.archdaily.com/478633 / tamedia-office-building-shigeru-ban-architects (accessed on 12 December 2019).

Shigeru Ban Architects. 2017. The inventive work of Shigeru Ban at Sherman Contemporary Art Foundation. Available online: http:/ / www.shigerubanarchitects.com/works/2017_SCAF/index.html (accessed on 10 March 2021).

Sickman, Laurence, and Aleksander Soper. 1984. Sztuka i Architektura w Chinach. Warszawa: Państwowe Wydawnictwo Naukowe, pp. 378-482, ISBN 83-01-03592-7.

Slavid, Ruth. 2005. Wood Architecture. London: Laurence King Publishing, pp. 136-39.

Stamp, Elizabeth. 2018. The Complete Works of Kengo Kuma Show the Dynamic Powers of Japanese Architecture. Available online: https: / / www.architecturaldigest.com/gallery/complete-works-kengo-kuma-dynamic-powers-japanese-architecture (accessed on 15 October 2020).

Sumiyoshi, Torashichi, and Gengo Matsui. 1991. Wood Joints in Classical Japanese Architecture, Japan: Publisher Janos Nagy. Available online: https / / www.wood-joints-in-classical-japanese-architecture.pdf (accessed on 29 November 2019).

Tajchman, Jan, and Andrzej Jurecki. 2020. Historia Technik Budowlanych. Warszawa: Wydawnictwo Naukowe PWN SA, ISBN 978-83-0121212-4.

Walker, Connor. 2014. Material Masters: Shigeru Ban's Work with Wood. Available online: https://www.archdaily.com/573818 / material-masters-shigeru-ban-s-works-work\%20-with-wood?ad_medium=widget\&ad_name=chrome-extension (accessed on 21 November 2020). 